His career was not spectacular but it was built on the foundation of complete probity and integrity and was, therefore, one of solid achievement. $\mathrm{He}$ possessed in full measure those qualities, including a kind of innate philosophy, from which real values spring and which make a man a worthy member of the community. He was forceful in argument, indeed somewhat blunt of tongue, but lacked nothing in kindness or in tolerance. He was respected for the independence of his judgment in business matters, and leading people in the City and elsewhere came to have very great respect for his financial acumen.

He took a life-long interest in sport of all kinds and, in particular, in athletics. He was no mean runner in his day. He helped to found the Insurance Athletic Association and was, in fact, attending amateur athletic meetings right up to the time of his death.

Above all, he was intensely loyal to the Company that he served and was ever watchful of the interests of the staff who served under him and who, without exception, regarded him with affection. In this respect, it was typical of the man that in his will he left a present to those who were on his staff at the date of his retirement, who had served for five years previously and who were still alive at the time of his death.

For all these reasons he will long be remembered by his personal friends and by his business colleagues. He has left this world, but his influence will remain.

E. H.L.

\title{
JOHN ARTHUR JEFFERSON
}

ON 2 November 1956, at the age of 73, John Arthur Jefferson died of a heart attack after a long period of indifferent health. Born at West Bromwich, he was the son of Frederick Thomas Jefferson, a prominent business man of that town.

After being educated at King William's College, Isle of Man, Jefferson worked successively in a chartered accountant's office, a stockbroker's office, and T. G. Ackland's office, and studied for the Institute examinations. In 1906 he joined the staff of the Britannic as Assistant Secretary, and became Secretary in I9I0 on qualifying as a Fellow. He was appointed General Manager in 1916 and became, additionally, Chairman of the Company in 1924. $\mathrm{He}$ thus held executive office for over $5^{\circ}$ years, and for 44 of those years he worked in close association with the late James Murray Laing. They formed a very fine combination, and the Company made great progress. To commemorate Jefferson's 50 years of service, the Company's staff subscribed for a portrait by Frank Salisbury, which was unveiled and hung in the Board Room in May 1956.

Jefferson had an exceptionally fine physique, and during his residence in London captained Rosslyn Park and represented Middlesex at rugby football. He was a useful cricketer and tennis player, had a low golf handicap and in later life enjoyed shooting, yachting and photography; but his main interest was his business, at which he worked hard.

Apart from his managerial duties including the management of a very large indoor and outdoor staff, he had a natural flair for investment work, and long before it became fashionable he invested shrewdly and successfully in equity shares. He was interested in staff welfare, and took a leading part in the provision of sports facilities and the setting up of the Company's staff and widows' pension funds. Although never engaged on the actuarial side of the 
business and often disclaiming any actuarial knowledge, there can be no doubt that his actuarial training gave him a most useful background.

During the greater part of his business life, industrial assurance was under political attack, and he took a leading part in defending it by his work for the Industrial Life Offices Association and by giving evidence before committees of inquiry. He had a gift for leadership which was evident, and he was called upon to fill such posts as President of the Birmingham Insurance Institute during a Conference Year, Chairman of the Industrial Life Offices Association for nine years, and Chairman of the British Insurance Association; the latter was an unusual honour for a man living in the provinces or connected with an industrial assurance office.

Jefferson enjoyed entertaining and was a generous and thoughtful host. $\mathrm{He}$ was a founder member of the Denarius Club and was also a member of the Actuaries and Gallio Clubs. He leaves a widow and three sons, one of whom recently became General Manager of the Britannic.

K. J. B.

\section{DAVID HOUSEMAN}

David Houseman, who died 7 December 1956, was born 30 April 1892, his father being the headmaster of the St Marylebone Grammar School. He gained an open scholarship to the City of London School, and on leaving school joined the staff of the London Life in January I910. During the 1914-18 War he served with the York and Lancaster Regiment, attaining the rank of Captain; he was wounded twice and was mentioned in dispatches. In 1919 he qualified as an Associate of the Institute but later turned his attention to the law. Having been articled in 1920 to $\mathrm{Mr} \mathrm{A}$. E. Savill of Messrs Druces and Attlee he was admitted a solicitor in 1923 and returned to the staff of the London Life, of which he was appointed Secretary in 1953, after being for many years its Trust and Claims Secretary.

Though Houseman had not achieved his original goal, the Fellowship, he remained a loyal member of the Institute and read papers before it on The new Law of Property Act (in 1925) and The Legal Aspects of Life Assurance Practice (in I931); for the former paper he received a prize from the Messenger and Brown Prize Fund. He took part in discussions at the Institute on various occasions and contributed several reviews to the fournal. For the last nine years of their publication he was joint author with MrE. J. MacGillivray of the Fournal's Legal Notes. His book, The Law of Life Assurance, is a worthy companion, albeit in a narrower field, to MacGillivray's magnum opus. He was a founder member and a past chairman of the Life Assurance Legal Society.

Houseman's was a delightful personality and his loyalty to his colleagues and his Company was of the highest order. His extreme modesty and the generous way in which he made his considerable knowledge available to all who sought his aid gained him a wide circle of friends and admirers in the world of life assurance. He possessed a whimsical sense of humour and his writings were often pointed by quotations from Lewis Carroll and Jerome K. Jerome.

F.H.W. 